\title{
Advances in Antarctic geoscience studies: Indian contributions
}

Former Directors, National Centre for Polar and Ocean Research, Goa 403804, India

Email: rasikravindra@gmail.com; rajan.ncaor@gmail.com

(Received : 16/01/2019; Revised accepted : 10/05/2019)

https://doi.org/10.18814/epiiugs/2020/020037

Indian contributions to Antarctic geosciences have been growing at a steady pace since last four decades or so, especially after the establishment of a national centre dedicated to polar studies (National Centre for Polar and Ocean Research, NCPOR). Several national organizations, laboratories and universities have contributed to the country's endeavors in Polar geosciences in varied fields such as structure and tectonics, metamorphism, geochronology, palaeoclimatology, sedimentology, seismo-tectonics, palaeomagnetism, and other related branches to generate a wealth of scientific data. The area of operations has been spread over parts of Central Dronning Maud land and the Larsemann Hills of Prydz Bay in East Antarctica, that expose poly-metamorphic deformed terrain with imprints of both the Grenville and Pan African orogeny. The geoscientific studies have focused on crustal evolution and geodynamics of the Antarctic continent and best fit model for India and Antarctic prior to the Gondwana amalgamation and split. Deep seismic profiles and related studies have revealed the subsurface nature of crust while other geophysical studies include geomagnetism and movement of Antarctic plate, ground penetrating radar surveys. The limnological studies, nature of surface sediments, sediments from melt water lakes, their provenance and microtextures etc, have been covered in another paper in this volume.

\section{Introduction}

Antarctica occupies the central stage in the studies on amalgamation and breaking up of continents during the multimillion year history of evolution of the Earth's crust. However, the impetus in the advancement of Polar sciences, including the geosciences, gained momentum only after the International Geophysical Year of 1957-58. In the early years, the Schirmacher and other areas of East
Antarctica (Enderby land etc.) received attention from the scientists of the-then USSR (Ravich and Kamenev, 1972; Ravich, 1982; Kamenev, 1982; Ravich and Soloviev, 1966, etc.) and the-then East Germany (Kampf and Stackebrandt, 1985; Kaiser and Wand, 1985; Bormann and Fritzsche, 1995). The Indian contributions to Antarctic geosciences commenced from the early 1980's after its first scientific expedition under the leadership of Dr S Z Qasim set foot on the icy continent on January 9, 1982. Over the years, the Indian Polar program has evolved with the successful completion of 38 expeditions to Antarctica to date (2018-19), establishment of three permanent research stations (Dakshin Gangotri located on the ice-shelf; Maitri, on ice free Schirmacher Oasis; and Bharati in the Larsemann Hills area; Figure 1) and extending the sphere of the country's scientific activities to the Arctic and the Southern Ocean. The annual expeditions to Antarctica have drawn scientists from several national organizations, laboratories and universities, enabling the the initiation of many multidisciplinary endeavors aimed at a better understanding of the continent. While the initial years were mostly periods of general reconnaissance around the Schirmacher Oasis, by the late 1980s sustained thematic and regional geological and geophysical studies had spread over the more interior mountain ranges of Wohlthat (Gruber, Petermann, Humboldt), Orvin and Muhlig-Hofmann Mountains, and further inland to Gjelsvkfjella Mountain, in parts of Central Dronning Maud land and to the Larsemann Hills area of Prydz Bay in East Antarctica (Figure 2). An area of $20,000 \mathrm{~km}^{2}$ has been covered by systematic geological mapping, thematic structural and metamorphic mapping by Indian geoscientists and detailed regional geological and geomorphologic maps have been published (Jayaram and Bejarniya, 1991; Geological Survey of India, 1998, 2006a,b).

Periodic reviews of the Indian contributions are available in Ravindra et al. (2008), Ravindra and Rahul Mohan (2011), Ravindra (2012), Nayak (2017), Pant et al. (2017a,b) etc.

\section{Regional Geology}

\section{Central Dronning Maud Land}

The sustained geological mapping that commenced in 1983 from the Schirmacher Oasis,-part of the mountain chain circling the coastal area of central Dronning Maud Land of East Antarctica- (cf. Sengupta, 1986a; Singh, 1986; Ravikant and Kundu,1998; D’Souza and Chakraborty, 2000; Rao et al., 2000), stretched to Gruber (Kaul et 


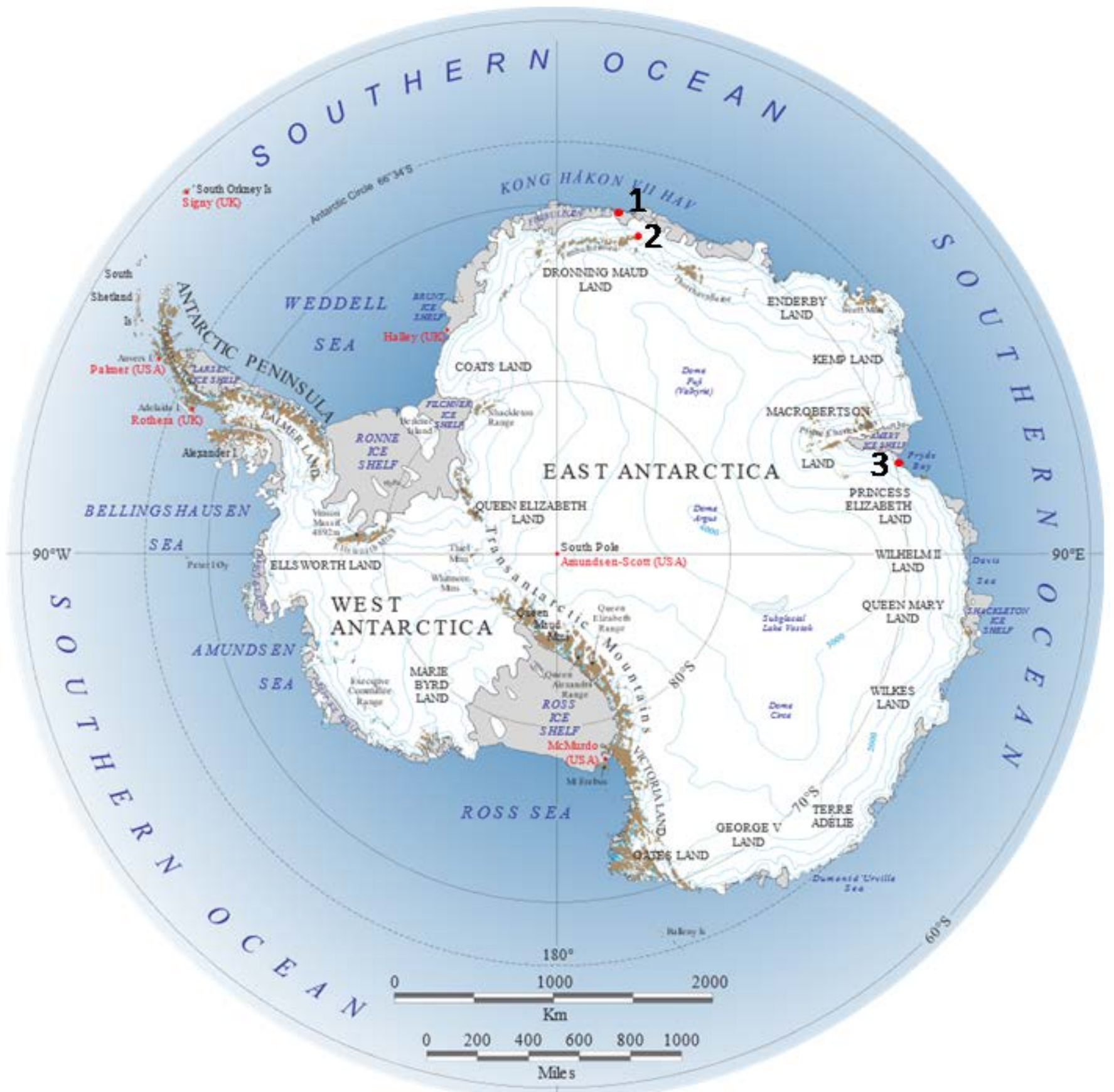

Figure 1. Map of Antarctica showing the locations of the three Indian research bases, (1) Dakshin Gangotri (now abandoned); (2) Maitri, and (3) Bharati. Map extracted from http://lima.nasa.gov/pdf/A3_overview.pdf, Public Domain, https://commons.wikimedia.org/w/ index.php? curid $=9570048$

al.,1987), Petermann Ranges (Joshi et al., 1991; Joshi and Pant, 1995), Humboldt (Ravindra et al., 1991), Payer-Weyprecht and Skeids Mountains, (Bejarniya et al., 1995; D’Souza et al., 1995), OrvinConrad (Bejarniya et al., 1998), Muhlig-Hofmanfjella (D'Souza et al., 2006), and further to Stabben-Jutulsessen nunataks in Gjelsvkfjell Mountains (Dharwadkar et al., 2017), covering a vast region of Central Dronning Maud land of East Antarctica between $2^{\circ} \mathrm{E}$ and $15^{\circ} \mathrm{E}$ longitudes and extending up to the last southern exposures close to the Polar Plateau (Figure 2). Subsequent to the opening of yet another sector in Prydz Bay, the region encompassing Larsemann Hills and adjoining promontories was also covered by detailed structural and metamorphic mapping (Beg and Asthana, 2012; Nath et al., 2016; Roy, et al., 2017).

The Schirmacher Oasis- a coastal oasis on the Princess Astrid coast of Central Dronning Maud land (CDML) - represents a polymetamorphic and extensively deformed terrain exposing garnet- biotite gneiss, augen gneiss; inter-banded mafic granulite, khondalite, calcsilicate and charnockite (Sengupta, 1986a,b; Singh, 1986). Mafic granulite with hypersthene-plagioclase and/or two- pyroxeneplagioclase, garnet-sillimanite gneiss and khondalite have also been mapped as dominant litho-units. Kaul et al. (1987) identified three mineral assemblages in the gneisses of the area, viz. 


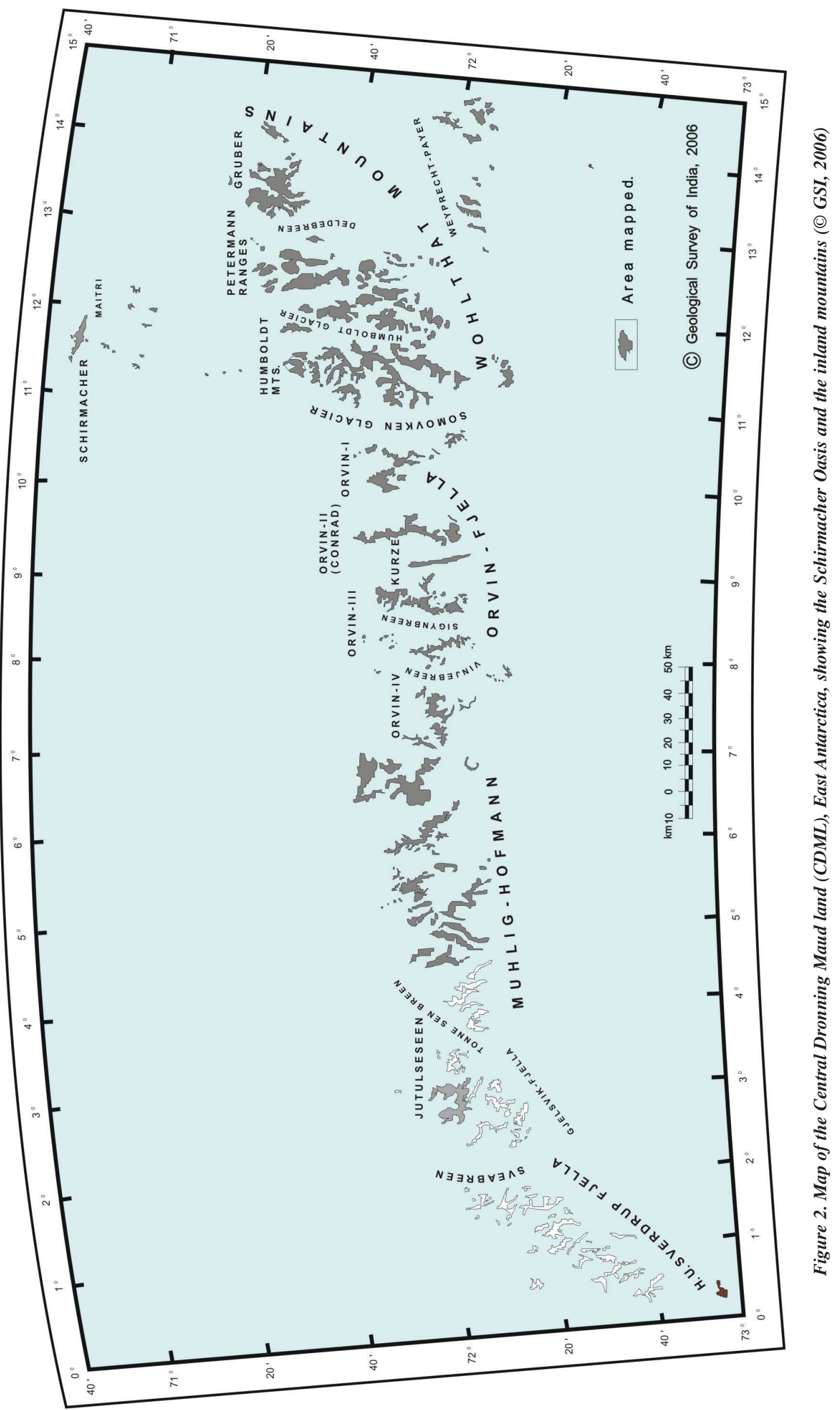


i. Garnet-orthopyroxene-clinopyroxene-perthite-plagioclasequartz \pm apatite

ii. Garnet- biotite -hornblende -perthite -plagioclase - quartz \pm apatite \pm zircon \pm ilmenite: and

iii. Quartz-plagioclase-garnet-perthite-orthopyroxene apatite \pm ilmenite

The tectonothermal, structural and metamorphic history of these high grade rocks has been worked out by many workers (e.g. Sengupta, 1986a, b, 1993; Kaul et al., 1991; Bose and Hazra, 2000; Bose and Sengupta, 2003). The first event of metamorphism $\left(\mathrm{M}_{1}\right)$, as per Ravikant and Kundu (1998) took place at $750-800^{\circ} \mathrm{C}$ temperatures under $8 \mathrm{kbar}$ pressure followed by $\mathrm{M}_{2}$ isothermal decompression at $750^{\circ} \mathrm{C}$. This was associated with syn- $\mathrm{D}_{2}$ Charnockite dyke intrusions. An isobaric cooling of rocks at 5-6 kbar pressure $\left(\mathrm{M}_{3}\right)$ followed. The $\mathrm{M}_{4}$ metamorphism responsible for a retrogressive phase has also been widely recognized. They have described the reaction textures and have drawn retrograde pressure-temperature-deformation paths from the granulite rocks.

The structural history as deciphered by Sengupta (1986b) shows an early deformation $D_{1}$ present only as tectonic layering. The rocks subsequently underwent four generations of superposed folding. The $\mathrm{F}_{2 \mathrm{a}}$ (isoclinals, rootless intrafolial folds with high amplitude/ wave length ratios) and $\mathrm{F}_{2 \mathrm{~b}}$ (isoclinal, very tight, occasionally highly asymmetric) folds were followed by $\mathrm{F}_{3}$ folding that represents a set of upright folds with plunge towards SSW. The $\mathrm{F}_{4}$ phase of folding is shown by asymmetrical folds with steep axial planes and very low plunge towards east or west. The last generation of folds $\left(\mathrm{F}_{5}\right)$ represents a weak localized deformation. Bose and Hazra (2000) have proposed that granulites exposed in the eastern parts have been thrust over the amphibolitic rocks along a thrust zone that occurs at the contact of augen gneiss and inter-layered calc-khondalite unit. The lamprophyre dykes that intrude the gneisses of Schirmacher have been described as alkaline and calc-alkaline types based on their geochemical characteristics (D'Souza et al., 1994; D'Souza and Chakraborty, 2000; Prasad et al., 2000).

The area lying between Schirmacher Oasis and the Wohlthat massif exposes a number of nunataks namely Tallaksenvarden, Stenersenknatten, Baalsrudfjellet, Hauglandtoppen, Sonstebynuten, Starheimtind, Pevikhornet etc. and others such as Austree and Midtre lying north of the Petermann ranges. These nunataks have been investigated by Kaul et al. (1991), Roy et al. (2017) and others, who have described the geology and petrography of the gneisses, basic granulites and quartz-syenite rocks exposed therein.

The nature and petrography of the Anorthosite Massif exposed in the Gruber Mountains as intrusives into Late Mesoproterozoic orthogneisses and other supracrustal rocks, and its magmatic history have been described by Mukerji et al. (1988) and Ravikant et al. (2011). Mukerji et al. (1988) point out the alkali enrichment and silicarich nature of these anorthosites while drawing a similarity of these anorthosite to those of Adirondack (USA) and Perinthatta (India) Ravikant et al. (2011) have classified the rocks marginal to the anorthosite massif as ferro-monzodiorite and ferro-monzonite. They postulate that the magma from which the anorthosite crystallized has been contaminated by crustal material that now occurs as enclaves within it. The marginal ferromonzodiorite represent hybridization of injected primitive ferrodiorite magma with preexisting crustal material resulting in hybrid ferromonzodiorite.

The Petermann ranges and Zwiesel Mountains located west of the Gruber Mountains occur as three parallel elongated ranges (Figure
2). The rocks here comprise low pressure granulites with minor calcsilicates, intrusive charnockite suite and A-type granites (Joshi et al., 1991; Joshi and Pant, 1995; Bejarniya et al., 1995; Dharwadkar et al., 2016). The charnockites have been described as comprising rocks varying from ferrogabbro- ferromonzogabbro- monzonitemonzosyenite to charnockite derived from a probable source of distinct magma enriched with lower crust or mantle.

The Humboldt Mountains occupying the western margin of Wohlthat Mountains reveal that the dominant lithounits exposed in the area are complexly deformed high grade metamorphites comprising interbedded two-pyroxene granulites, khondalites, amphibolites, charnockites and calc silicates (Pant, 1991; Ravindra et al., 1989; Ravindra et al., 1994; Bejarniya et al., 1995; D’Souza et al., 1995; Ravindra and Pandit, 2000). The rocks have undergone granulite facies metamorphism. The garnet is largely grossularite. Biotite is titaniferous and iron rich. PGM bearing meta-ultramafites have been reported from northern parts of Humboldt (Ravindra et al., 1989), based on the EPMA scan of the meta-ultramafite assemblages. Ravindra and Pandit (2000) also assign whole rock Rb$\mathrm{Sr}$ isochoron age of $514 \pm 59 \mathrm{Ma}$ to the granites exposed in Nordvestoya, in the northern parts of the Humboldt Mountains. Late Proterozoic granitic orthogneisses in the Payer-Weyprecht Mountains, south of Gruber and Petermann ranges, have been assigned an age of 749 \pm 61 Ma by whole rock Rb-Sr (Ravikant et al., 1997). Similar orthogneisses appear to be present in the Skeids area in the Southern parts of Humboldt (D’Souza et al., 1995).

The Muhlig-Hofmannfjella Mountains, exposed towards the eastern parts of Central Dronning Maud land have been shown by D'Souza et al. (2006) as comprising basal gneisses, charnockites and intrusive granites. The granitoid pluton, essentially of monzogranitequartz monzonite composition contains restites of orthogneisses and charnockites, which have been correlated with the Svarthmaren charnockites present in the western Muhlig-Hoffmanfjella that have been dated at $500 \pm 24$ Ma by Ohta et al. (1990).

Stabben - Jutulsessen in the Gjelsvikfjella area located in the farthest western parts of the CDML exposes predominantly para and orthogneisses represented by biotite gneiss, biotite-garnet gneiss, quartzo-feldspathic and granite gneiss (Dharwadkar et al., 2017). The orthogneiss consists of amphibolitic and biotite rich enclaves. Gabbro, syenite, minor granite, pegmatite and aplite form the intrusive suite. Chemically, the gneisses are of monzogranite-granodiorite composition whereas the mafic dykes have a basalt-andesiterhyodacite composition. The area has undergone a complex geological history involving at least three deformational episodes with concomitant metamorphism. In the Stabben area, a non foliated intrusive gabbro pluton as well as intrusive syenite limits the gneisses. The para-gneisses represented by biotite and biotite-garnet gneisses may have a sedimentary protolith whereas the orthogneisses are igneous in origin. The mineral assemblage of K-feldspar- PlagioclaseBiotite with or without garnet indicates amphibolite facies peak metamorphic conditions for the orthogneiss. Occurrence of orthopyroxene within the amphibolitic enclaves suggests an earlier granulite-grade event. A peak temperature of formation of garnet of $483^{\circ} \mathrm{C}$ within the orthogneiss and $628^{\circ} \mathrm{C}$ for the same within diorite enclave has been obtained. Amphibolite facies metamorphism is indicated by feldspar crystallization temperature of $\sim 450^{\circ} \mathrm{C}$. Recent geochronological studies assign an age of $1170 \mathrm{Ma}$ to $970 \mathrm{Ma}$ for the migmatites/gneisses and an emplacement age of $501 \mathrm{Ma}$ for the Stabben gabbro and syenite. 


\section{Weddell Sea region}

Reconnaissance of the Filchner Ice Shelf and Berkner Island area along with Littlewood, Bertrab and Moltke nunataks in the Weddell Sea area was undertaken during 1989-90 Antarctic season. While nunatak Littlewood exposes rhyolites, granites and acid volcanic and basic rocks intruded by dolerite dykes have been mapped in Bertrab nunatak (Raina, et al. 1995). The Moltke nunatak exposes limestone interbedded with foliated lithic arkose rock.

\section{Larsemann Hills}

The Larsemann Hills area along the east Antarctic margin of Prydz Bay, encircling the Ingrid Christensen Coast, lies along the northern extension of the eastern Indian Cratonic belts of Bastar, EGMB, Singhbhum, etc. of the East Gondwanaland - East Antarctica tectonic framework. Preliminary geological studies undertaken by Beg and Asthana (2012) and Nath et al., (2011, 2016) indicate that there are three distinct genetically different suites of rocks exposed in the study area - i) an igneous suite composed of granitoids (tonalite, granodiorite and Progress Granite), ii) metamorphosed igneous suite (garnetiferous granite-granodiorite gneiss and pyroxene granulites) and iii) the metamorphosed sedimentary suite (sillimanite gneiss and mgt \pm sill \pm cord bearing metapelites). Structural analysis has revealed that the pervasive and persistent regional foliation planes (S1 and S2) are near-parallel and are the result of two phases of deformation $\mathrm{DF}_{1}$ and $\mathrm{DF}_{2}$ respectively. There is a third phase of folding $\mathrm{F}_{3}$ documented in the study area which represents the $\mathrm{DF}_{3}$ deformation.

The rocks in the Larsemann Hills region document a diachronous geological evolutionary history that shows a Palaeoproterozoic felsic/ gneissic basement over which supracrustal sequence of pelitic, psammitic paragneisses were deposited (Pandit, 2016). The rocks have undergone two major phases of metamorphism at ca $\sim 1 \mathrm{Ga}$ and during early Palaeozoic- the latter, a medium to low pressure granulite facies metamorphism at $\sim 7 \mathrm{kbar}$ pressure and $800-850^{\circ} \mathrm{C}$ temperature. A detailed work on the complicated basement-cover rocks of the Larsemann Hills area, their relationship and the time frame was carried out by Ghosh et al. (2017).

\section{Crustal Evolution and India-Antarctica correlation}

The East African Orogen (EAO), is an $3000 \mathrm{~km}$ long orogen, extending from Jordan and Israel in the North (Arabian Nubian Shield, ANS) to Madagascar-Mozambique in the South. The EAO has been suggested to extend into East Antarctica through the Lutzow-Holm Bay and to CDML. A large number of individual cratonic segments viz., India (in the East) and Kalahari, Sahara etc (in the West) were sutured in the world's largest Neoproterozoic orogen. Orogen styles within EAO varies from $\mathrm{N}$ to $\mathrm{S}$. ANS is an accretion-type orogen with an oblique convergence of bounding plates; the orogen involving the Cabo Delgado Nappe Complex is opined to be a hot- to ultra-hot orogeny whereas, Madagascar- Tanzania is considered to be of the Himalayan type. The passage of EAO in these regions is not very well established mainly because of the paucity of continuous rock exposures. Following Jacobs et al. (1998), there have been a number of workers who have attempted to fill in the missing information (Jacobs and Thomas, 2002; Jacobs et al., 2003, 2008; Mikhalasky et al., 2006; Pant et al., 2013 etc.).
Several contributions have been made by Indian geoscientists of late towards understanding the crustal evolutionary history of parts of Central Dronning Maud Land (CDML) and the Larsemann Hills and their correlation with the Indian landmass vis-a-vis their position in Gondwanaland. The southern extension of the East African Orogen (EAO) comprising Mesoproterozoic rocks of Grenvillian orogeny (Stern, 1994) into the coastal mountain ranges of CDML (Jacobs et al., 1998; Jacobs and Thomas, 2002 etc.) through the NNW-SSE trending rocks of Schirmacher Oasis, Humboldt Mountains and the isolated exposures of various nunataks between the Schirmacher Oasis and Wohlthat Mountains (such as Baalsrudfjellet), has been recognized by many workers (Ravikant et al., 2007; Baba et al., 2006; Pant et al., 2013; Roy et al., 2017, and references therein).

Both the CDML and Larsemann Hills regions expose Mesoproterozoic poly-deformed, magmato-metamorphic terrain of high-grade rocks that have undergone granulite grade of metamorphism. The southern extension of EAO is believed to have acted as a suture between the east and west Gondwana blocks during Neoproterozoic (Pant et al., 2013 and references therein). Based on electron microprobe dating of the monazite grains, Pant et al. (2013) have opined that metamorphic neocrystallisation began in Neoproterozoic at 640-650 Ma time and continued up to $580 \mathrm{Ma}$. The 500-600 Ma magmatic activity is widespread in CDML.

Based on similarities of granulites representing $660 \mathrm{Ma}-600 \mathrm{Ma}$ (Stern, 1994) to those of Schirmacher (Ravikant et al., 2004, 2007; Baba et al., 2006), the EAO has been extended to Antarctica through Schirmacher. The rocks of Schirmacher have been shown to be late Neoproterozoic. There are differences in the interpretation of the metamorphic paths in Schirmacher Oasis, from isobaric heatingisothermal decompression-isobaric cooling (Ravikant and Kundu, 1988) to isobaric cooling during retrograde metamorphism (Baba et al.2006). Nonetheless there is a general consensus about the clockwise $\mathrm{P}-\mathrm{T}-\mathrm{t}$ paths and the timing of peak metamorphism to be significantly younger than was envisaged earlier (Baba et al., 2008, 2010), thus establishing an affinity with the EAO. Structurally, the NE-SW trending shear zones and mylonites in Schirmacher that show flow planes parallel to the regional foliation of East African Orogeny are believed to have evolved during the late phase of D2/M2 to early D3/ M3 tectonothermal event. Based on the regional setting, the nature and timing of these shear zones and their association with the retrogressive amphibolite facies metamorphism, these zones are suggested to be a part of exhumation (D'Souza et al., 2011; Pant et al., 2017b).

The intervening $\sim 100 \mathrm{~km}$ vast ice covered stretch between Schirmacher Oasis in the North and Wohlthat Mountains in the South is by and large devoid of much geological information excepting for those from a few isolated small hill tops which rise above the Polar Ice sheet. One such nunatak is Baalstudfjellet. The rocks exposed in Baalsrudfjellet consist of an inter-banded sequence of quartzofeldspathic gneiss, pyroxene granulite, metapelite with intrusives like lamprophyre and quartz veins. The mineral assemblage of $\mathrm{pl}+\mathrm{qtz}+\mathrm{bt}+\mathrm{grt}+\mathrm{opx}+\mathrm{amph}$ indicates granulite facies peak metamorphic conditions. The bulk composition of quartzo-feldspathic gneiss is comparable with upper crust with a moderate REE enrichment. Tectonic discrimination plots indicate a syn-collision setting for the quartzo-feldspathic gneiss. The metapelite is represented by the mineral assemblage $\mathrm{qtz}+\mathrm{bt}+\mathrm{pl}+\mathrm{grt}+\mathrm{sil}$. The peak metamorphism for metapelite is estimated at $635^{\circ} \mathrm{C}$ at $6-7 \mathrm{Kbar}$ pressure. Two-pyroxene geothermometry indicates a peak temperature of $730^{\circ} \mathrm{C}$ at $6-7 \mathrm{Kbar}$. 
The oldest date obtained from monazite within the metapelite of $\sim 584 \mathrm{Ma}$ indicates that the area is part of EAO. Based on lithological, metamorphic, structural, geochronological similarities the EAO has been hypothesised to pass through the nunatak (Roy et al., 2017).

The P-T fluid histories inferred from the study of calc-silicate rocks of Baalsrudfjellet have been correlated with those from Kerala Khondalite Belt (KKB) and the Highland complex of Sri Lanka (D'Souza et al., 2012). The calc-silicate rocks interlayered with the metasedimentary units show a mineral assemblage of forsterite-spinelcalcite-dolomite-plagioclase-biotite and scapolite-wollastonitediopside-plagioclase with development of coronal garnet. The mineral assemblages and the reaction textures have helped to constrain the $\mathrm{P}$ T fluid history which suggests metamorphism at temperatures of $900^{\circ} \mathrm{C}$ under high pressure ( $\sim$ 9kbar) conditions. The calc silicate rocks and the marble show the effect of amphibolite facies retrogression under the influence of high $\mathrm{H}_{2} \mathrm{O}$ content and reduced $\mathrm{XCO}_{2}$ value.

The metamorphic neocrystallization began in Neoproterozoic time ( $\sim 640$ to $650 \mathrm{Ma}$ ) and continued upto $\sim 580 \mathrm{Ma}$ extending for $\sim 60$ $\mathrm{Ma}$ and was marked by the development of low to intermediate pressure granulite-grade assemblages, partial melting and generation of in situ crystallization of granitic melt by biotite dehydration melting (Pant et.al. 2013). The protracted metamorphism was overprinted by a strong thermal imprint at $\sim 540 \mathrm{Ma}$ which is correlatable with large scale charnockite and A-type granite emplacements. Extensive panAfrican thermal imprint in the Wohlthat Mountains is represented by anorthosite ( $600 \mathrm{Ma})$, charnockite and anorogenic granite. The range of ages for the younger charnockites and anorogenic granites is within 500-550 Ma (Mikhalasky et al., 1997) signifying a possibility of multiple phase of AMCG magmatism in Dronning Maud Land. The Humboldt Mountain granulites, like Schirmacher Oasis and Baalsrudfjellet Nunatak indicate an initial isobaric heating (continental collision and crustal thickening) reaching upto the sillimanite stability field followed by unroofing, thus, defining clockwise P-T-t paths. The younger magmatic activity, spread on both East and West of the narrow zone of $\sim 640$ Ma granulites, shows anorogenic characteristic (Joshi et al., 1991; Joshi and Pant, 1995) and appears to be unrelated to the granulites. The zone of $\sim 640$ Ma granulite grade metamorphism is inferred as the remnant of suture between East and West Gondwana (Pant et al., 2013).

Dharwadkar et al. (2017) have recorded the presence of orthopyroxene within the amphibolitic enclaves in Gjelsvkfjella Mountains, in the western margin of CDML, suggesting an earlier granulite grade event. Geochronological studies assign an age of 1170 to $970 \mathrm{Ma}$ for the migmatites/gneisses and an emplacement age of $501 \mathrm{Ma}$ for the Stabben gabbro and syenite.

The Larsemann Hills in the Prydz Bay region of East Antarctica offers a key setting for correlation between the East Antarctica and the Eastern Ghat Belt of eastern India. The study of Grenvallian ( 1000 Ma)-Pan-African ( $500 \mathrm{Ma})$ high grade tectono-metamorphic evolutionary history of the Prydz Bay, including Larsemann Hills and its adjoining areas like Sostrene Islands, Bolingen Islands, Brattstrand Bluffs, Rauer Islands, Vestfold Hills etc. is significant in the present-day reconstruction and correlation with India and east Antarctica.

The major rock types exposed in the Larsemann Hills area are: garnetiferous granite; granodiorite gneiss; orthopyroxene bearing granite representing the metamorphosed acid igneous suite; pyroxene granulite representing the metamorphosed basic igneous suite and the metapelite representing the metamorphosed sedimentary suite. Small scale quartzo-feldspathic melts (migmatite) are also preserved at a few locations. The post tectonic igneous suite is represented by small patches of granitoids. Relicts of older amphibolites and mafic enclaves occur as rafts and enclaves within the garnetiferous gneiss (Mandal and Roy, 2008; Nath et al., 2011).

The reconstruction of metamorphic history by Nath and Shah (2013) reveals that the earliest phase of metamorphism $\left(M_{1}\right)$ is represented by the inclusion assemblage of quartz-biotite-plagioclaseilmenite/magnetite in amphibole suggesting a prograde metamorphic event. The $M_{1 b}$ phase is well represented by the inclusion assemblage magnesio- hestingsite / pergasite-quartz-plagioclase-biotite \pm ilmenite in $\mathrm{Opx} / \mathrm{Cpx}$ and also Opx/Cpx corona around amphibole, ilmenite and plagioclase (zoned), suggesting a progressive prograde metamorphic event along with a deformational phase represented by preferred orientation of mineral grains. The peak metamorphic grade $\mathrm{M}_{2}$ assemblage has been defined by the mineral association of OpxGarnet \pm biotite \pm ilmenite \pm quartz where the amphibole is totally an absent phase and garnet appears (possible P-T condition may be $\mathrm{T}$ $>850^{\circ} \mathrm{C}, \mathrm{P}>5 \mathrm{~kb}$ ). The $\mathrm{M}_{3}$ metamorphic event is largely explained by near-isothermal decompression and cooling phenomenon represented by inclusion assemblage of Opx-Cpx-garnet in green amphibole, biotite, plagioclase, ilmenite, presence of symplectites of biotitechlorite-muscovite/sericite-plagioclase-quartz and biotite-Opx; corona of biotite, cordierite around ilmenite/spinel/sillimanite and the inclusion of Bt-Hbl-Opx-Ilm-Mag-tourmaline in Prismatine etc.

The mineral assemblages and inclusion of sillimanite in garnet and cordierite, and amphibole in pyroxenes have helped in building the metamorphic history of the Larsemann Hills region. The peak metamorphic P-T condition calculated by conventional geothermobarometry is $843^{\circ} \mathrm{C}$ at $\sim 6 \mathrm{~kb}$ for the pyroxene granulites and $805^{\circ} \mathrm{C}$ at $\sim 6 \mathrm{~kb}$ for the metapelites. The retrograde path is defined by the isothermal decompression due to exhumation (uplift) after reaching the peak (granulite grade) followed by isobaric cooling to lower amphibolite- grade metamorphic conditions.

A similar thermobarometry has been noted in the of the metamorphites of the Anantagiri-Araku areas of the Eastern Ghats with exsolution of pigeonite at $\sim 950^{\circ} \mathrm{C}$, clinopyroxene in orthopyroxene and vice versa at $750-820^{\circ} \mathrm{C}$ and formation of garnet at around $700-725^{\circ} \mathrm{C}, 7 \mathrm{~kb}$. This indicates a nearly isobaric cooling path subsequent to peak metamorphic conditions. Subsequent retrograde events that occurred at a lower temperature of $\sim 523^{\circ} \mathrm{C}$ in $490 \pm 14 \mathrm{Ma}$ are quite evident from the P-T calculation and chemical dating of monazite. Similar Pan-African ages are also reported from various pockets of the Eastern Ghats.

$\mathrm{U}-\mathrm{Pb}-\mathrm{Th}$ chemical dating of monazite reveals that the prograde isobaric heating might have been triggered at the waning stage of the Grenvillian Orogeny ( $850-900 \mathrm{Ma})$, where heat budget was provided by the process of crustal thinning. This process might have continued up to $600-550 \mathrm{Ma}$ to reach the peak condition with the high P-T sustained by the crustal rejuvenation related to collision tectonics during Pan-African Orogeny. The post peak retrograde phases represented by the isothermal decompression commenced at $550 \mathrm{Ma}$ and culminated at $\sim 490$ Ma through isobaric cooling.

\section{Geomorphology}

Geomorphologic studies constitute an integral part of the geoscience investigations in CDML (Ravindra, 2001; GSI, 2006a; 
Ravindra, 2013) and Larsemann Hills area (Asthana et al., 2013a and $b$ ).

The Schirmacher Oasis and Larsemann hills display a rolling topography constituted by low-lying hills, devoid of sharp peaks as opposed to interior parts of CDML which exhibit typical alpine morphology with sharp peaks, horns etc. A thin moraine cover is omnipresent in Schirmacher, displaying the retreating ice mass over the Oasis subsequent to the Last Glacial Maximum. Larsemann Hills are believed to have been ice-free much earlier (Kiernan et al. 2009). Glacial striations and polishing are evident on hard rocks at both places. The sharp vertical escarpment, faulting and comparatively higher relief on the northern margin is displayed in Schirmacher, suggesting an isostatic rebound that caused the uplift of the ice-free oasis. Several erosional and depositional landforms such as honey comb weathering, cavernous pits, en-echelon pattern of Rôche moutonnée and depositional features e.g. moraines, patterned ground etc. have been mapped in Schirmacher Oasis (Ravindra, 2013). The hundred-odd melt water lakes of Schirmacher have also attracted the attention of many workers. These lakes have been classified genetically as proglacial, landlocked and epishelf lakes (Ravindra, 2001). The alignment of most of these lakes have been found to follow some lineaments which define the palaeo course of the glaciers moving from ice sheet to the shelf, in general NNE or NW directions. The two contrasting polar and periglacial environments of Schirmacher and Larsemann Hills of East Antarctica have been discussed by Asthana et al. (2013a,b).

Landscape evaluation of Humboldt and adjoining area in Wohlthat Mountain by Ravindra et al. (1991) has shown both polar and alpine type of morphologic set up. The vast stretch of highly crevassed ice sheet separates the Wohlthat massif from Schirmacher Oasis, with occasional nunataks in between, depicting the typical polar environment. The sky line is constituted by sharp serrated ridge tops with arêtes and jagged peaks and horns in the Gruber, Petermann, Humboldt and Orvin Mountains that rise abruptly to $2188 \mathrm{~m}$ above the m.s.l. at Hjornehorna.

Shrivastava et al. (2012) have identified four distinct geomorphological units in the Schirmacher region, viz. the shelf, piedmont zone, the mountain barrier or the structural hills and the Polar ice plateau. They have also identified a number of dry glacial valleys and about 122 small remnant glaciers on the upper mountain slopes.

\section{Geophysical studies}

Gravity, magnetic and GPS studies are useful in finding out the structural features, plate motions and crustal deformation of the continent. Verma et al. (2003) describe the 95 line-km magnetic traverses carried out on the ice shelf giving the structural model of the area around Dakshin Gangotri. The studies around Schirmacher Oasis include 13 multi-frequency electromagnetic (EM), magnetic, and radiometric traverses. Helicopter-borne magnetic and helicoptersupported gravity surveys over Schirmacher and the area lying between Schirmacher and Wohlthat Mountains have yielded gross features of the subglacial topography, with the maximum thickness of the ice in the region being about $3.5 \mathrm{~km}$ to the south of Schirmacher. The Moho thickness has been found to vary from $38 \mathrm{~km}$ below the Humboldt Mountains to about $32 \mathrm{~km}$ below the Schirmacher, reflecting the gradual reduction of the crustal thickness from the continental margin below the Wohlthat Mountains towards the deep ocean.
Analyzing the GPS data from fifty sites in Antarctica, including that from Maitri Station (MAIT), Ghavri et al. (2017) estimate the velocity of movement of Antarctic plate to be less than about 4mm / year in the eastern part of East Antarctica and about 20mm/year in the western part of West Antarctica. The estimated velocity of movement at Maitri is about $8 \pm 1 \mathrm{~mm} /$ year, towards north.

The crustal and lithospheric structure beneath the Antarctic ice have been deciphered using Space-borne gravimetry and other geophysical and geological information (Ravikumar et al., 2018). In general, the oldest Archean and Proterozoic crust of East Antarctica has a thickness of $45 \mathrm{~km}$ where as the youngest rifted continental crust of the West Antarctic Rift System has a thickness of $25 \mathrm{~km}$. Structural variability is reflected both in the thickness and the physical properties of the crust. Other significant features such as the mantle differences between east and west Antarctica, and the thinning of the lithosphere in west and its thickening in east Antarctica similar to that of other stable cratons, have also deciphered from the geophysical data.

The study of geomagnetic processes and monitoring of reverse magnetic flux in the outer core of the Earth at Maitri attain significance because of the station's ideal location in a sub-auroral region. Indian scientists have been operating a Fluxgate Magnetometer (FM) at Maitri for recording variations in the three orthogonal components of the surface geomagnetic field, X, Y and Z or the Daily Variations (DV). Round-the-year collection of magnetic data commenced in 1986-87, while the three-stations magnetometer network has been intermittently operational for short periods between 1991 and 1997 for estimation of the velocity of current system moving over Maitri. Continuous recording of the geomagnetic field and magnetic pulsations (from two stations) is being carried out since 1991. The data are being recorded in both analogue and digital forms. Apart from FM, a Riometer has also been installed to record the radio signal strength of the cosmic radio noise at ground. Nearly three decades of experimental geomagnetic data has revealed the importance of Maitri as ideally suitable for now-casting geo-space weather and the interplanetary weather studies (Rajaram, et al. 2001).

Intermittent recording of the absolute values of total magnetic field (F) by a Proton Precession Magnetometer (PPM) and the comparison of the results with data of PPM and FM have shown a rapidly declining magnetic field over the past 75 years at Maitri and other southern hemisphere stations. The magnetic flux at Maitri has been reported to decline to $60 \mathrm{nT} / \mathrm{yr}$ from 120nT/yr during 1995-96 (Pathan, et al. 2009).In addition, cosmic noise absorption (CAN) has been measured using imaging Riometer to get an insight into D-region ionospheric conditions its dynamics (Sinha, et al. 2017).

\section{Concluding remarks}

The Indian geoscientific studies in Antarctica have witnessed a steady and sustained growth over the past nearly four decades, ever since the First Indian Scientific Expedition to Antarctica (1981-82). From summer-time reconnaissance around the Schirmacher Oasis during the initial years, the country's Indian Antarctic program has slowly reoriented itself into long-term national plans in tune with international priority settings. The establishment of a national institution (NCPOR) devoted to a leadership role in the study of the polar regions and two year-round Antarctic research bases (Maitri in the Schirmacher Oasis and Bharati in the Larsemann Hills) have led to many multi-institutional and co-operative multi-national scientific 
activities spread over a larger spatial extent. Considering that Antarctica was a keystone of Gondwana of which the Indian landmass was an intrinsic part, the prime focus of the geological and geophysical studies by Indian scientists has been naturally on the crustal evolution and geodynamics of the Antarctic continent and a best fit model for India and Antarctica prior to the Gondwana amalgamation and split. Concurrently, the scope of other geoscientific investigations has also widened to include such frontier areas of study as the palaeoclimatic evolution of Antarctica as decipherable from the proxy records of ice cores and marine and lake sediment archives (for example, see Meloth, this volume, for a comprehensive review of Indian contributions to Antarctic paleoclimatic studies), the role of subglacial morphology and bedrock geological structure on the dynamics of the glaciers, crust and mantle thickness determinations through remote sensing and geophysical techniques etc. Looking ahead, India's research endeavours in Antarctic geosciences are poised to realign themselves to a portfolio of cross-disciplinary and multi-national initiatives in tune with the roadmap for the Antarctic and Southern Ocean sciences for the next two decades and beyond, as outlined by the 1st Scientific Committee on Antarctic Research (SCAR) Antarctic and Southern Ocean Science Horizon Scan (Kennicutt II et al. 2014a, b).

\section{References}

Arora, D., Pant, N.C., Fareeduddin., Sharma, S., Raghuram., and Sadiq, M., 2017 Inferring a Neoproterozoic Orogeny preceding the Rodinia break-up in the Sirohi Group, NW India, In: N. C. Pant and S. Dasgupta (Eds.) Crustal Evolution of India and Antarctica: The Supercontinent Connection, Geological Society of London Special Publication 457, pp319-336.https://doi.org/ 10.1144/SP457.14

Asthana, R., Shrivastava, P.K., Beg, M.J., Swain, A.K., Dharwadkar, A., Roy, S.K., and Srivastava, H.B., 2013a Sedimentary processes in two different polar periglacial environments: Examples from Schirmacher Oasis and Larsemann Hills, East Antarctica, Geological Society of London Special Publication v. 381, p411427.

Asthana, R., Shrivastava, P.K., Srivastava, H.B., Beg, M.J., and Kumar, P., 2013b Hydrochemistry and sediment characteristics of polar periglacial lacustrine environments on Fisher Island and Broknes Peninsula, East Antarctica, Advances in Polar Science, v.24, p281-295.

Baba, S., Owada, M., Grew, E.S., and Shiraishi, K., 2006, Sapphirineorthopyroxene-garnet-granulite from Schirmacher Hills, Central Dronning Maud Land, In: D.K. Fütterer., D. Damaske., G. Kleinschmidt., H. Miller and F. Tessensohn (Eds.) Antarctica: Contributions to Global Earth Sciences, Springer, Berlin, pp3744.

Baba, S., Owada, M., and Shiraishi, K., 2008, Contrasting metamorphic P-T path between Schirmacher and MühligHofmannfjella, central Dronning Maud land, East Antarctica, In: M. Satish-Kumar., Y. Motoyoshi., Y. Osanai., Y. Hiroi and K. Shiraishi (Eds.) Geodynamic evolution of East Antarctica: A key to the East-West Gondwana connection, Geological Society of London Special Publication, 308, pp401-417. https://doi.org/ 10.1144/SP308.20.

Baba, S., Hokada, T., Kaiden, H., Dunkley, D.J., Owada, M., and Shiraishi, K., 2010, SHRIMP U-Pb dating of sapphirine-bearing granulite and biotite-hornblende gneiss in the Schirmacher Hills, East Antarctica: implications for Neoproterozoic ultrahightemperature metamorphism prefacing the assembly of Gondwana, Journal of Geology, v. 118, p621-639.
Beg, M.J., and Asthana, R., 2012, Geological studies in the Larsemann Hills, Ingrid Christensen coast, East Antarctica, Scientific Report, 24th Indian Expedition to Antarctica, Technical Publication No.22, Ministry of Earth Sciences, New Delhi, pp363-367.

Bejarniya, B.R., Ravikant, V., Mukerji, S., Nautiyal, S.C., Oberoi, L.K., and Gill, A.S., 1995, Geology of Payer-Weyprecht Mountains, Central Dronning Maud Land, East Antarctica, Technical Publication No. 9, Department of Ocean Development, New Delhi, India.

Bejarniya, B.R., Ravikant, V., and Kundu, A., 1998, Field relationship and petrological studies of rocks from Conrad Mountains, Central Dronning Maud Land, East Antarctica, Scientific Report Fourteenth Indian Expedition to Antarctica, Technical Publication, Department of Ocean Development, New Delhi, India.

Bormann, P., and Fritzsche, D. (Eds.), 1995, The Schirmacher Oasis, Queen Maud land, East Antarctica and its surroundings, Justus Perthes Verlag, Gotha, 448pp.

Bose, S., and Hazra, S., 2000, Structural analysis of the western parts of Schirmacher hills, east Antarctica, Technical Publication No. 14, Department of Ocean Development, New Delhi, India.

Bose, S., and Sengupta, S., 2003, High Temperature Mylonitization of Quartzofeldspathic gneiss: Example from the Schirmacher Hills, East Antarctica Gondwana Research, v.6, p 805-816.

Bose, S., Dunkley, D.J., Dasgupta, S., Das, K., and Arima, M., 2011, India-Antarctica-Australia-Laurentia connection in the Palaeoproterozoic- mesoproterozoic revisited: evidence from new zircon $\mathrm{U}-\mathrm{Pb}$ and monazite chemical age data from the Eastern Ghats Belt, India, Geological Society of America Bulletin, v.123, p2031-249.

Bose, S., Seth, P., and Dasgupta, N., 2017, Meso-Neoproterozoic mid-crustal metamorphic record from the Ajmer-Shrinagar section, Rajasthan, India and its implication to the assembly of the Greater Indian Landmass during the Grenvillian age orogenies, In: N.C. Pant and S. Dasgupta (Eds.) Crustal Evolution of India and Antarctica: The Supercontinent Connection, Geological Society of London Special Publication 457, pp291-318.https:// doi.org/10.1144/SP457.14

Chatterji, A., Das, K., Bose, S., Ganguly, P., and Hidaka, H., 2017, Zircon-U-Pb SHRIMP and monazite EPMA-U-Th-total Pb geochronology of granulites of the western boundary, Eastern Ghats Belt India: a new possibility for Neoproterozoic exhumation history, In: N.C. Pant and S. Dasgupta (Eds.) Crustal Evolution of India and Antarctica: The Supercontinent Connection, Geological Society of London Special Publication 457, pp105140.https://doi.org/10.1144/SP457.14

Das, E., Kamarkar, S., Dey, A., and Sengupta, P., 2017, Reaction Textures, pressure-temperature paths and chemical data of monazite from a new suite of saphirine-spinel granulites from parts of the Eastern Ghat Province, India: Insight into the final amalgamation of India and East Antarctica during the formation of Rodinia, In: N.C. Pant and S. Dasgupta (Eds) Crustal Evolution of India and Antarctica: The Supercontinent Connection, Geological Society of London Special Publication 457, pp141170.https://doi.org/10.1144/SP457.14.

Dasgupta, S., Bose, S., Bhowmik, S. K., and Sengupta, P., 2017, The Eastern Ghats Belt, India in the context of supercontinent assembly, In: N.C Pant and S. Dasgupta (Eds) Crustal Evolution of India and Antarctica: The Supercontinent Connection, Geological Society of London Special Publication 457, pp87104.https://doi.org/10.1144/SP457.14.

Dharwadkar, A., Nath, A.K., Shrivastava, P.K., and Jayapaul, D., 2016, Geology of the Gruber and Zweissel Granitoids, Central Dronning Maud land, East Antarctica, Technical Publication . No 24, National Centre for Antarctic and Ocean Research. Goa, India. 
Dharwadkar, A., Shrivastava, P.K., and Shrivastava, H.B., 2017, Tectonometamorphic Evolution of Jutulsessen, Gjelsvikfjella, CDML, East Antarctica, Journal of the Geological Society of India, v. 92, p265-280.

D’Souza, M.J., Beg, M.J., Ravindra, R., and Chaturvedi, A., 1994, Occurrence of Alkaline lamprophyres Dyke from the Schirmacher Range, Technical Publication No. 6, Department of Ocean Development, New Delhi, India.

D’Souza, M.J., Beg, M.J., Ravindra, R., Chaturvedi, A., and Kaul, M.K., 1995, Geology of Skeids Area, Humboldt Mountains, Wohlthat Range, Central Dronning Maud Land, east Antarctica, Technical Publication No. 6, Department of Ocean Development, New Delhi, India.

D'Souza, M.J., Kundu, A., and Kaul, M.K., 1996, The geology of Central Dronning Maud Land (CDML), east Antarctica, Indian Minerals, v.50, p323-338.

D'Souza, M.J., and Chakraborty, S.K., 2000, Petrology of Early Palaeozoic lamprophyres from Schirmacher Oasis, east Antarctica, Journal of the Geological Society of India, v.56, p593-604.

D’Souza, M.J., Keshava Prasad, A.V.K., and Ravindra, R., 2006, Genesis of ferropotassic A-Type granitoids of MuhligHofmanfjella, central Dronning Maud land, east Antarctica, In: D.K. Fütterer., D. Damaske., G. Kleinschmidt., H. Miller and F. Tessensohn (Eds.) Antarctica: contributions to global earth sciences, Springer, Berlin, pp45-54. DOI: 10.1007/3-540-32934X_6.

D’Souza, M.J., Roy, S.K., Swain, A.K., and Dharwadkar, A. 2011, Detailed study of Schirmacher mylonites to determine formation time and stress, strain, temperature involved in their formation as an implication to exhumation history, Report of the Geological Survey of India (unpublished).

D’Souza, M.J,, Nath, A.K., Swain, A.K., Shrivastava, P.K., Mandal, A., and Dharwadkar, A., 2012, Modeling the Pan-African Calc Silicate rocks of Central Dronning Maud Land, East Antarctica with reference to $\mathrm{CaO}-\mathrm{Al}_{2} \mathrm{O}_{3}-\mathrm{SiO}_{2}-\mathrm{CO}_{2}$ System. Geological Survey of India report (unpublished).

Geological Survey of India, 1998, Geological map of Schirmacher Oasis, Central Dronning Maud Land, East Antarctica (Scale 1:25,000), GSI, Hyderabad, India

Geological Survey of India, 2006a, Geomorphological Map of Schirmacher Oasis, East Antarctica on 1:25,000 scale, GSI, Hyderabad, India

Geological Survey of India, 2006b, Geological Map of Orvinfjella, Central Dronning Maud Land,, East Antarctica on 1:50,000 scale, GSI, Hyderabad, India.

Ghavri, S., Catherine, J.K., Ambikapathy, A., Kumar, A., and Gahalaut, V.K., 2017, Antarctic Plate Movement, Proceedings of the Indian National Science Academy, 83, p437-440.

Ghosh, J.G., Roy, S.K., Sadiq, M., and Kato, A., 2017, Relationship between Orthogneiss and Paragneiss of the rocks of Larsemann Hills, Unpublished GSI report.

Jacobs, J., and Thomas, R.J., 2002, The Mozambique Belt from an East Antarctic perspective, In: J.A. Gamble., D.N.B. Skinner and S. Henrys (Eds.) Antarctica at the close of a Millennium, Proceedings of the $8^{\text {th }}$ International Symposium on Antarctic Earth Sciences, Royal Society of New Zealand Bulletin, v.35, pp3-18.

Jacobs, J., Klemd, R., Fanning, C.M., Bauer, W., and Colombo, F., 2003, Extensional collapse of the late Neoproterozoic/early Palaeozoic East African/Antarctic Orogen in central Dronning Maud Land, In: M. Yoshida., B.F. Windley and S. Dasgupta (Eds.) Proterozoic East Gondwana: Supercontinent assembly and breakup, Geological Society of London Special Publication 206, pp273-287.

Jacobs, J., Fanning, C. M., Henjes-Kunst, F., Olesch, M., and H.J. Paech, 1998, Continuation of the Mozambique Belt into East Antarctica: Grenville age metamorphism and polyphase Pan-
African high-grade events in Central Dronning Maud Land, The Journal of Geology, v. 106, p385-406.

Jacobs, J., Bingen, B., Thomas, R.J., Bauer, W., Wingate, M., Feitio, P., 2008. Early Palaeozoic orogenic collapse and voluminous latetectonic magmatism in Dronning Maud Land and Mozambique. Insights into the partially delaminated root of the East AfricanAntarctic Orogen? In: M. Satish-Kumar., Y. Motoyoshi., Y. Osanai., Y. Hiroi and K. Shiraishi (Eds.) Geodynamic evolution of East Antarctica: A key to the East-West Gondwana connection, Geological Society of London Special Publication, 308, 69-90. https://doi.org/10.1144/SP308.20.

James, P.R., and Tingy, R.J., 1983, The Precambrian geological evolution of the East Antarctic metamorphic shield-a review, In: R.L. Oliver., P.R. James and J.B. Jago (Eds.) Antarctic Earth Science, Australian Academy of Sciences, Canberra, pp 5-15.

Jayananda, M., Banerjee, M., Pant, N.C., Dasgupta, S., Kano, T., Mahesha, N., and Mahabaleswar, B., 2011, 2.62 Ga hightemperature metamorphism in the central part of the Eastern Dharwar Craton: implications for late Archaean tectonothermal history, Geological journal, v. 47, p213-236. http://dx.doi.org/ 10.1002.gj.1308

Jayaram, J., and Bejarniya, B.R., 1991, Geological Map of Schirmacher-Wohlthat Region, Central Dronning Maud land, East Antarctica, 1:25000, Geological Survey of India, Hyderabad.

Joshi, A., and Pant, N.C., 1995, Petrology, geochemistry and evolution of the charnockite suite of the Petermann ranges, East Antarctica, In: M. Yoshida and M. Santosh (Eds.) India and Antarctica during the Precambrian, Memoirs of the Geological Society of India, v. 34, pp241-258.

Joshi, A., Pant. N.C., and Parimoo, M.L., 1991, Granites of Petermann ranges, East Antarctica and implications on their genesis, Journal of the Geological Society of India, v. 38, p169-218.

Kaiser, G., and Wand, U., 1985, K-Ar dating of basalt dykes in the Schirmacher Oasis, Dronning Maud Land, Antarctica, Isotope in Antarctic research, Akademie der Wissenschaften der DDR, Zentralinstitut für Isotopen- und Strahlenforschung. ZFIMitteilungen, 89, pp. 123-132.

Kamenev, E.N., 1982, Regional metamorphism in Antarctica, In: C. Craddok (Ed.) Antarctic Geoscience, Symposium on Antarctic geology and geophysics, Madison, Wisconsin, 1977, The University of Wisconsin Press, Wisconsin, pp429-433.

Kampf, H., and Stackebrandt, W., 1985, Geological investigation in the Eliseev anorthosite massif, central Dronning Maud Land, East Antarctica, Zeitschrift fur. Geologische Wissenschaften, 13, p3260.

Kaul, M.K., Singh, R.K., Srivastava, D., Jayaram, S., and Mukerji, S., 1987, Petrological and structural characteristics of a part of east Antarctic Craton, Queen Maud land, Antarctica, In: M.R.A. Thompson., J.A. Crane and J.W. Thomson (Eds.) Geological Evolution of Antarctica, Cambridge University Press, Cambridge, pp89-94.

Kennicutt, M.C., Chown, S.L. , Cassano, J.J., Liggett, D., Massom, R., Peck, L.S., Rintoul, S.R., Storey, J.W.V., Vaughan, D.G., Wilson, T.J., and Sutherlan, W.J., 2014a, Polar research: six priorities for Antarctic science, Nature, v. 512, p23-25. doi:10.1017/S095410201400067.

Kenicutt. M.C., et al., 2014b, A roadmap for Antarctic and Southern Ocean science for the next two decades and beyond, Antarctic Science, First View, 1-16. doi:10.1017/S0954102014000674.

Kiernan, K., Gore, D., Fink, D., and Sigurdsson, I.A., 2009, Deglaciation and weathering of Larsemann Hills, East Antarctica, Antarctic Science, v.21, p373-382. DOI: 10.1017/ S0954102009002028

Kundu, A., D'Souza, M.J., and Mohan, A., 1998, Reaction Textures in gneisses from Dallmannfjellet-Conrad Area, Orvin Range, Central Dronning Maud land, East Antarctica: Implication for 
metamorphic Evolution, Journal of the Geological Society of India, v. 52, p709-719.

Mandal, A., and Roy, S.K. 2008, Correlation of the crustal evolutionary history of Larsemann Hills area, east Antarctica and Eastern Ghats, India. Report of the Geological Survey of India (Unpublished).

Mikhalasky, E.V., Sheraton, J.W., and Hahne, K., 2006, Charnockite composition in relation to the tectonic evolution of East Antarctica, Gondwana Research, v. 9, p379-397.

Mikhalasky, E.V., Beliatsky, B.V., Savva, E.V., Wetzel, H.U., Fedorov, L.V., Weiser, T., and Hahne, K., 1997, Reconnaissance geochronologic data on polymetamorphic and Igneous rocks of the Humboldt Mountains, East Antarctica, In: C. A. Ricci (Ed.), The Antarctic Region: Geological Evolution and Processes, Terra Antarctica Publication, Siena, Italy, pp. 45-53.

Mukerji, S., Kaul, M.K., Singh, R.K., Srivastava, D., and Jayaram, S., 1988, Anorthosites of Gruber Massif, Central Queen Maud Land, East Antarctica-An appraisal, Technical Publication No. 5, Department of Ocean Development, New Delhi.

Mukherjee, S., Dey, A., Sayal, S., Ibanz-Mejia, M., Dutta, U., and Sengupta, P., 2017, Petrology and U-Pb geochronology of zircon in a suite of charnockitic gneisses from the parts of the Chotanagpur granite Gneiss Complex (CGGC): evidence for the reworking of a Mesoproterozoic basement during the formation of the Rodinia supercontinent, In: N.C. Pant and S. Dasgupta (Eds.) Crustal Evolution of India and Antarctica: The Supercontinent Connection, Geological Society of London Special Publication 457, pp197-232. https://doi.org/10.1144/ SP457.14.

Nath, A.K ., and Shah, M.Y., 2013, Geological mapping of the South Grovnes Peninsula, Larsemann Hills, East Antarctica, to establish a correlation of lithostratigraphic and tectono-metamorphic evolutionary history with the North Grovnes peninsula (Bharati promontory), Report of the Geological Survey of India (Unpublished).

Nath, A.K., D'Souza, M.J., and Mandal, A., 2011, Correlation of crustal evolutionary history of Larsemann Hills, East Antarctica and Eastern Ghats, India, Report of the Geological Survey of India (Unpublished).

Nath, A.K., Dharwadkar, A., and Shrivastava, P.K., 2016, Preliminary geological Investigation at Larsemann Hills, East Antarctic during $26^{\text {th }}$ Indian Antarctic Expedition, Technical Publication No. 24, National Centre for Antarctic and Ocean Research, Goa, India.

Nayak, S., 2017, Recent Antarctic Research in India: The National Committee Report to SCAR, Proceedings of the Indian National Science Academy, v.83.

Ohta, Y., Torudbakken, Bo., and Shiraishi, K., 1990, Geology of Gjelsvikfjella and western Muhlig-Hofmannfjella, Dronning Maud Land, east Antarctica, Polar Research, v. 8, p538-544.

Pandit, M.K., 2016, Magnetic fabric studies in Larsemann Hills, Prydz Bay region, East Antarctica, In: D. Jaypaul (Ed.), Report of 26th Indian Scientific Expedition to Antarctica, Technical Publication No. 24, National Centre for Antarctic and Ocean Research, Goa, India.

Pant, N.C., 1991, Metamorphic evolution of Humboldt- mountains, Dronning Maud Land, East Antarctica (Unpublished Ph.D. thesis, M.L. Sukhadia University, Udaipur, India).

Pant, N.C., Kundu, A., Joshi, S., Dey, A., Bhandari, A., and Joshi, A., 2009, Chemical dating of monazite: testing of an analytical protocol against independently dated standards, Indian Journal of Geosciences, v. 63, p311-31.

Pant, N.C., Kundu, A., D’Souza, M.J., and Saikia, A., 2013, Petrology of the Neoproterozoic granulites from Central Dronning Maud land, east Antarctica- Implications for southward extension of
East African Orogen (EAO), Precambrian Research, v.227, p389408.

Pant, N.C., and Dasgupta, S., 2017a, An Introduction to the Crustal evolution of India and Antarctica: the supercontinent connection, In: N.C. Pant and S. Dasgupta (Eds) Crustal Evolution of India and Antarctica: The Supercontinent Connection, Geological Society of London Special Publication 457, pp1-6. https://doi.org/ 10.1144/SP457.14.

Pant, N.C., Roy, S., Ravikant, V., and Ravindra, R., 2017b, Recent contributions to the Antarctic Geology -An Indian Perspective, Proceedings of the Indian National Science Academy, v.83, Thematic Issue 2017, pp269-278. DOI: 10.16943/ptinsa/2017/ 48948

Pathan, B.M., Dhar, A., Asinker, A.L., Selvamurugan, R., and Hanchinal, A.N., 2009, Declining magnetic field at Maitri, Antarctica, Indian Journal of Geosciences, v. 63, p187-194.

Prasad, A.V.K., Beg, M.J., and D’Souza, M.J., 2000, Petrography of lamprophyre dikes from nunataks southeast of Schirmacher Oasis, CDML, East Antarctica, Current Science, v.81, p219-225.

Raina, V.K., Rao, V.D., Mukerji, S., Gill, A.S., and Dotiwala, F., 1995, Geology of the nunataks- Littlewood, Bertrab and Moltke in Weddell Sea area, West Antarctica. Indian Expedition to Weddell Sea, Antarctica, Scientific Report 1995, Geological Survey of India, pp25-54.

Rajaram, G., Dhar, A., and Kumar, A., 2001, Response of geomagnetic variations and $30 \mathrm{MHz}$ Riometer absorption at Indian Antarctic Station Maitri, to conditions of "Zero" and "High" solar wind, Advances in Space Research, v. 28, p1661-1667.

Rao, R.D., Rashid, S.A., and Panthulu, G.V.C., 2000, Origin of MgMeta tholeiites of the Schirmacher Region, East Antarctica: Constraints from Trace Elements and Nd-Sr Isotopic Systematics, Gondwana Research, v.3, p91-104.

Ravich, M.G., 1982, The lower Precambrian of Antarctica, In: C. Craddok (Ed.) Antarctic Geoscience. Symposium on Antarctic Geology and Geophysics, Madison, Wisconsin, 1977, The University of Wisconsin Press, Wisconsin, pp421-427.

Ravich, M.G., and Soloviev, D.S., 1966, Geology and petrology of the central parts of the Mountains of Central Dronning Maud Land, Eastern Antarctica, Transactions of the Scientific Research Institute of the Geology of the Arctic, Leningrad, p141 (in Russian).

Ravich, M.G., and Kamenev, E.N., 1975, Crystalline Basement of the Antarctic Platform, John-Wiley, New York, 582pp.

Ravikant, V., 1998, Preliminary Thermal modelling of the massif anorthosite-charnockitic gneiss interface from Gruber Mountains, Central Dronning Maud land, East Antarctica, Journal of the Geological Society of India, v. 52, p287-300.

Ravikant, V., and Kundu, A., 1998, Reaction textures of retrograde pressure temperature-deformation paths from granulites of Schirmacher Hills, East Antarctica, Journal of the Geological Society of India, v. 51, p305-314.

Ravikant, V., Bejarniya, B.R., Mukerji, S., and Kaul, M.K., 1997, Late Proterozoic granitic orthogneisses from Payer-Weyprecht Mountains, East Antarctica: their tectonometamorphic history and regional correlation, In: C.A. Ricci (Ed.) The Antarctic Region: Geological Evolution and Processes, Siena, Italy, pp55-63.

Ravikant, V., Dharwadkar, A., Golani, P.R., and Ravindra, R., 2011, Petrology and geochemistry of the Grubergebirge anorthosite and marginal rocks, Central Dronning Maud Land: Further characterization of the Late Neoproterozoic magmatic event in East Antarctica, Journal of the Geological Society of India, v.78, p7-18.

Ravikant, V., Laux, J.H., and Pimentel, M.M., 2007, Sm-Nd and U$\mathrm{Pb}$ isotopic constraints for crustal evolution during Late 
Neoproterozoic from rocks of the Schirmacher Oasis, East Antarctica: geodynamic development coeval with East African Orogeny, In: A,.K. Cooper, C.R. Raymond et al., (Eds.) Antarctica: A Keystone in a Changing world, Online proceedings of the 10th ISAES, USGS Open-File Report 2007-1047, Short Research Paper 007, 5pp. doi:10.3133/of2007-1047.srp007.

Ravi Kumar, M., Bijendra Singh., Ramesh, D.S., Reddy, C.D., and Dhar, Ajay., 2018, Crustal and lithospheric structure beneath Antarctic Plate inferred from Gravimetry data, POLAR 2018SCAR Open Science Conference, Davos, Switzerland, June 1923, 2018.

Ravindra, R., 2001, Geomorphology of Schirmacher Oasis, East Antarctica, Proceedings of the Symposium on Snow, ice and glaciers, Geological Survey of India Special Publication No.53, pp379-391.

Ravindra, R., 2008, Antarctic Earth Science-Indian efforts, In: Harsh Gupta and Fareeduddin (Eds.) Recent Advances in Earth System Sciences, Memoirs of the Geological Society of India 66, pp521538.

Ravindra, R., 2012, Institutional Report on National Centre for Antarctic and Ocean Research, Proceedings of the Indian National Science Academy, v.78.

Ravindra, R., 2013, Evolution of Rocky Oases in eastern Antarctica: Studies by Indian Scientists, In: R. Ramesh, M. Sudhakar, and S. Chattopadhyay (Eds.) Scientific and Geopolitical Interests in Arctic and Antarctic: Proceedings of the International Conference on Science and Geopolitics of Arctic and Antarctic, (SaGAA), LIGHTS, Research Foundation, New Delhi, India, 296pp.

Ravindra, R., and Dey, A., 1992, Geological, geomorphological and glaciological studies carried out during Austral winter of 1990 at Antarctica, Records of the Geological Survey of India, v.125, pt2.

Ravindra, R., and Pandit, M.K., 2000, Geochemistry and Geochronology of A-Type Granite from Northern Humboldt Mountain, East Antarctica: Vestige of Pan-African Event, Journal of the Geological Society of India, v.56, p253-262.

Ravindra, R., and Rahul Mohan., 2011, Three decades of Polar Sciences in India, Geological Society of India, V.789, p1-3.

Ravindra, R., Pant, N.C., and D'Souza, M.J., 1989, A note on the PGM bearing metaultramafite from Humboldt Mountains in east Antarctica, Indian Minerals, v.43, p157-161.

Ravindra, R., Pant, N.C., and D’Souza, M.J., 1991, Landscape evaluation of Humboldt and adjacent areas, Wohlthat Mountains, East Antarctica, Journal of the Geological Society of India, v.37, p172-183.

Ravindra, R., Dey, A., D’Souza, M.J., Beg, M.J., and Kaul, M.K., 1994, On the gneisses and associated rocks from South Humboldt Mountains, Central Dronning Maud land, East Antarctica, Technical Publication No. 6, Department of Ocean Development, New Delhi, India.

Ravindra, R., Thamban, M., Rahul Mohan, and D’Souza, M.J., 2008, Antarctic Earth Sciences: Indian Perspective, In: A.K. Singhvi, A. Bhattacharya and S. Guha (Eds.) Glimpses of Geoscience Research in India, Indian National Science Academy, New Delhi.

Roy, S.K., Pant, N.C., Kundu, A., Dharwadkar, A., Kumar, P.K., Joshi, S., Raghuram, Sadiq, M., and Pandey, M., 2017, Geological studies in the Baalsrudfjellet nunatak and Wohlthat Mountains to establish the continuation of the East Antarctic Orogen (EAO) in the central Dronning Maud land, In: N.C. Pant and S. Dasgupta (Eds.) Crustal Evolution of India and Antarctica: The Supercontinent Connection, Geological Society of London Special Publication 457, pp37-60. https://doi.org/10.1144/ SP457.14.

Sawant, A.D., Gupta, S., Clark, C., and Mishra, S., 2017, The Rauer-
Rengali connection in the Indo-Antarctic amalgamation: evidence from structure, metamorphism and geochronology, In: N.C. Pant and S. Dasgupta (Eds) Crustal Evolution of India and Antarctica: The Supercontinent Connection, Geological Society of London Special Publication 457. https://doi.org/10.1144/SP457.14.

Sengupta, S., 1986a, Geology of Schirmacher Range (Dakshin Gangotri), East Antarctica, Technical Publication No. 3, Department of Ocean Development, New Delhi, India.

Sengupta, S., 1986b, Precambrian rocks of the Schirmacher Range, East Antarctica, Zeitschrift für Geologische Wissenschaften, v.16, p647-660.

Sengupta, S., 1993, Tectonothermal history recorded in mafic dykes and enclaves of gneissic basement in the Schirmacher Hills, east Antarctica, Precambrian Research, v.63, p273-291.

Shrivastava, P.K., Asthana, R., Beg, M.J., and Ravindra, R., 2011, Ionic Characters of Lake Water of Bharati Promontory, Larsemann Hills, East Antarctica, Journal of the Geological Society of India, v.78, p217-225.

Shrivastava, P.K., Asthana, R., Roy, S.K., Swain, A.K., and Dharwadkar, A., 2012, Provenance and depositional environment of epi-shelf lake sediment from Schirmacher Oasis, East Antarctica, vis-a-vis scanning electron microscopy of quartz grain, size distribution and chemical parameters, Polar Science, v.6, p165-182.

Shrivastava, P.K., Dharwadkar, A., Asthana, R., Roy, S.K., Swain, A.K., and Beg, M.J., 2014, The sediment properties of glacial diamicts from the Juttulsessen area of Gjelsvikfjella, East Antarctica: A reflection of source materials and regional climate, Polar Science, v.8, p264-282.

Singh, R.K., 1986, Geology of the Dakshin Gangotri hill range, Antarctica, Technical Publication No.3, Department of Ocean Development, New Delhi, India.

Sinha, A.K., Dhar, A., Singh, A.K., Behera, J.K., and Gurubaran, S., 2017, India's contribution to geomagnetism and allied studies in Antarctica-A review, Proceedings of the Indian National Science Academy, v.83, p299-326.

Srivastava, D., Kaul, M.K., Singh, R.K., Mukerji, S., and Jayaram, S., 1988, Some observations on the glacial geomorphological features of Wohlthat Mountains, Central Dronning Maud Land, Antarctica, Technical Publication No. 5, Department of Ocean Development, New Delhi, India.

Stern, R.J., 1994, Arc assembly and continental collision in the Neoproterozoic East African Orogen: implications for the consolidation of Gondwana land, Annual Review of Earth and Planetary Sciences, v.22, p319-351. https://doi.org/10.1146/ annurev.ea.22.050194.001535

Sunil, P.S., Reddy, C.D., Ponraj, M., Dhar, A., and Jayapaul, D., 2007, GPS determination of the velocity and strain rate field on Schirmacher Glacier, central Dronning Maud Land, Antarctica, Journal of Glaciology, v.53, p 558-564.

Sunil, P.S., Reddy, C.D., Ponraj, M., Dhar, Ajay, Jayapaul, D., and Dharwadkar, A., 2009, Determination of velocity vector of Schirmacher glacier (Dronning Maud Land, Antarctica) using GPS, Indian Journal of Geosciences, v.63, p 235-240.

Swain, A.K., and Goswami, S., 2014, Continuous GPR survey using Multiple Low Frequency antennas - case studies from Schirmacher Oasis, East Antarctica, International Journal of Earth Science and Engineering, v.7, p1623-1629.

Verma, S.K., Singh, B., Malaimani, E.C., Tiwari, V.M., Kishore, P., and Rao, M.B.S.V., 2003, Geoscientific research in Antarctica: Emerging trends in Indian Context, In: S. Rajan and P.C Pandey (Eds.) Proceedings of the National Seminar on Antarctic Geosciences, Ocean-Atmosphere interaction and Palaeoclimate, NCAOR, Goa, India. 


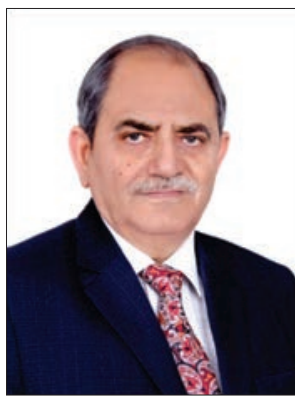

Dr. Rasik Ravindra, currently the Secretary General of $36^{\text {th }}$ International Geological Congress, held the position of Director, National Centre for Polar and Ocean Research, Goa between 2006 and 2012, after putting 35 years of active service with Geological Survey of India. He has conducted wide ranging geological surveys for mineral exploration and elucidation of stratigraphy in Precambrian terrains of Rajasthan, Meghalaya, Bhutan and Antarctica. Leader of the Ninth Antarctic Expedition, he also led the First Indian scientific Expedition to South Pole (2010-11), the First Indian Expedition to Arctic (2008), and expeditions to Higher Himalaya in Bhutan. Former Chair Panikkar Professor at Ministry of Earth Sciences and Member of the UN Commission on Limits of Continental Shelf he has been awarded National Mineral Award 1990, Antarctic Award 2002 and Life Time Achievement Award from Paleontological Soc. of India, 2017 among several others.

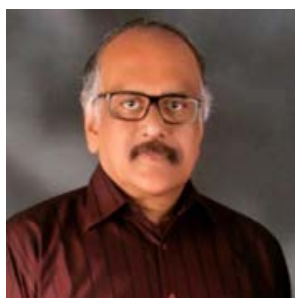

Dr. Rajan Sivaramakrishnan is a former Director of the Goa-based National Centre for Polar and Ocean Research (NCPOR). A Ph.D in Geology and Geophysics from the University of Hawaii, Dr. Rajan has nearly four decades of scientific experience focused on marine geoscientific studies and continental margin delineation, in the course of his career initially in the Geological Survey of India and subsequently at NCPOR, from where he retired in 2015. Leader of the Indian Continental Shelf Program between 1999 and 2012, he was India's elected representative to the UN Commission on the Limits of the Continental Shelf from 2007-13. 